\title{
Natural Gas Distribution Industry in Italy: Ongoing Changes and Emerging Problems at the Competitive Level
}

\author{
Federico Testa, Fabio Cassia, Angelo Bonfanti \\ University of Verona, Verona, Italy
}

\begin{abstract}
The natural gas distribution industry in Italy is undergoing profound reorganization. Italian legislators, by decree 164/2000 (the so-called Letta Decree), in compliance with EU guidelines, began liberalizing the natural gas distribution industry. Many regulatory and legislative acts were forthcoming in the following decade, redefining governance of this industry. Many legal and economic studies have been carried out on this matter. What is still lacking is an analysis that considers the effects on the intensity of competition of the Italian retail market, also and especially in light of the 2011 decrees (Decree January 19th, 2011 about tariff areas, Decree June 1st, 2011 about the Italian energy market and its transparency and Decree October 18th, 2011 about the assignment of each of the 8,092 Italian municipalities to a tariff area). This paper bridges this gap in research. The paper, through a qualitative approach, first considers and then discusses the expected results of the new regulation from a competitive-managerial standpoint. Specifically, it examines the changes and the effects on (1) the natural gas distribution industry; (2) the distribution companies; and (3) the users concerning: (a) structural; (b) economic; and (c) service quality dimensions. We suggest that only by considering the desired impacts at all three levels (industry as a whole-companies-users) is it possible to have a clear picture both of the benefits and of the pitfalls of the new legislation at the competitive level.
\end{abstract}

Keywords: natural gas distribution industry and companies, regulation, utilities service quality, users, efficiency, competitiveness

\section{Introduction}

In general the liberalization and privatization processes in the natural gas industry lead to an evolution of the natural gas market, generating dramatic changes in many countries.

The Italian natural gas distribution industry has been undergoing a process of liberalization since 1998, when the European Directive 98/30 was introduced. The purpose of the European legislation was to foster effective competition within the natural gas industry, which includes at least four different stages: extraction/importing; national transportation; local distribution; and sales (Erbetta \& Fraquelli, 2003; Testa \& Stagnaro, 2011). While extraction and sales are now open to competition, national transportation, and local distribution represent natural monopolies (Law 239 dated August 23rd, 2004, known as the Marzano Law).

Federico Testa, Full Professor, Department of Business Administration, University of Verona (Italy).

Fabio Cassia, Ph.D., Researcher and Assistant Professor, Department of Business Administration. University of Verona (Italy).

Angelo Bonfanti, Ph.D., Researcher and Assistant Professor, Department of Business Administration, University of Verona (Italy).

Correspondence concerning this article should be addressed to Fabio Cassia, University of Verona, Department of Business Administration, via dell’Artigliere, 19, 37129 Verona (Italy). E-mail: fabio.cassia@univr.it. 
In this paper, we focus in particular on local natural gas distribution in Italy. Given that each EU country had to acknowledge the mentioned EU Directive and to translate it into local legislative acts, it is relevant to investigate the implications of the regulatory choices at a national level. More specifically, four acts of the Italian government set the bases for the current regulation of the natural gas distribution in Italy: the so-called Letta Decree (164/00) and three other decrees in 2011 (Decree January 19th about tariff areas, Decree June 1st about the Italian energy market and its transparency, Decree October 18th about the assignment of each of the 8,092 Italian municipalities to a tariff area).

Before the liberalization process was started in 2000 the gas market was featured by the presence of a publicly-owned vertically integrated business (ENI) with a monopoly in the upstream phases of the supply chain (extraction/importing; national transportation) and a strong control even in the integrated distribution and sales activities, where it held an approximate 30\% market share. The remaining share was broken down among hundreds of businesses, generally small in size and owned by local authorities (Giacomelli, 2008).

In that context, the Letta Decree, acknowledging the mentioned EU Directive, made a distinction between potentially competitive activities (extraction and sales), now open to competition, and activities considered as natural monopolies (Giacomelli, 2008). Gas distribution was one of these activities and as such was subject to the usual regulatory instruments: technical and quality regulation, economic regulation (through a price cap mechanism managed by the Authority for Electricity and Gas), access obligations for all businesses at third-party and non-discriminatory terms (third-party access) and assignment of management through tenders (Testa, 2007; Antonioli, 2008; Stagnaro, 2011). Especially, this decree recognized gas distribution as unbundled from gas sale and stated that, in spite of their natural expiry date, all the existing concessions would have been expired and that they would have been granted again after a transitory period (decree 273 dated December 30th, 2005, known as Milleproroghe Decree).

During 2011 the three mentioned decrees were introduced to complete the governance framework of natural gas distribution. These acts are based on the assumption that a well-regulated competition for the field (Demsetz, 1959, 1964, 1968) through concession assignments can (almost) produce the same effects as the open market competition (Giacomelli, 2008). Moreover, following also the suggestions of the Italian Authority for Electric Energy and Gas (AEEG), the acts are based on the further assumption that high economies both of density and of scale are present in the Italian natural gas distribution industry.

Therefore it has been set that Italian municipalities should be grouped into 177 tariff areas, large enough to produce economies of scale, and that the concession for each of these 177 areas should be assigned to one gas distribution company only. This choice will imply a strong reduction in the current number of Italian natural gas distribution companies: they will drop from 247 (Ref, 2011) to 177 or less (given that it is likely that some companies will be able to be awarded the concession for more than one area). It should also be remarked that $42 \%$ of the shares of current gas distributors are currently still owned by public operators. The concession will be assigned through a tender according to the following elements of the technical bid (Ref, 2011): economic terms; safety and quality; the investment plan for the expansion and maintenance of the distribution network and equipment.

Researchers and practitioners are trying to understand the effects of the liberalization process (Giacomelli, 2008) and the results that such recently updated regulation will have on the Italian natural gas distribution scenario (Dorigoni \& Portatadino, 2009). Some of them have already anticipated some potential critical points, such as the risk of high entry barriers for new entrants, due to the amount of money that the new assignee has to 
pay to the previous assignee as compensation fee for the investments made in the distribution equipment. Some other scholars (Stagnaro \& Testa, 2009) have highlighted the confusion about the economies of density and the economies of scale, which guided AEEG's suggestion that each tariff area should be assigned to one company only.

In addition, difficulties in organizing the tenders for the concession have been predicted (Ref, 2011). Most important: in general available studies both by academic researchers and by practitioners mostly focus on legal and economic aspects at the industry level (Stagnaro, 2011).

The purpose of this paper is to integrate such analysis with an assessment of the expected results of the new regulation from a competitive-managerial standpoint, i.e., from the natural gas distribution industry and company perspective and from the natural gas users' standpoint. In particular, we focus on retail market (and not on the wholesale market), given that the regulation goes into this matter. Hence this paper aims at answering the following research questions:

(1) What kind of results will the new regulation have on the Italian gas distribution industry from a competitive-managerial perspective, i.e., on the industry as a whole, on the companies and on the users?

(2) What aspects at business level shall it affect mostly?

For the purpose of pursuing these objectives, the remainder of the paper is composed as follows. First of all an articulated range of studies and documents is reviewed and analyzed, including academic studies on natural gas distribution, legislative acts and reports from institutions and organizations, so as to underline the scarcity of contributions from the competitive-managerial standpoint. Thereafter, we explain our methodological choices and we present our results with the support of a summary table to classify expected dimensions of the new regulation influences on the:

(3) Natural gas distribution industry;

(4) Gas distribution companies;

(5) Users.

Finally we discuss our findings in a perspective of managerial implication. Conclusion, limitations, and further research complete the analysis.

\section{Literature Review}

The theme being analyzed is examined in Italian and international literature primarily from the legal and institutional standpoints.

Economic literature is also quite well developed, it dedicates great attention to studying the economic aspects of gas distribution and, in particular, to measuring the economies of scale when formulating distribution costs.

Little, on the other hand, is written on the natural gas distribution industry from a competitive-managerial analysis perspective. MacAvoy (2000), for example, takes a managerial standpoint but without reference to the gas distribution industry, highlighting the unbundling of merchant and transportation services for the purpose of creating a more competitive environment and discouraging the concentration of market power.

The review of literature is consequently divided into two steps: the first step considers the main research carried out in the economic sphere, exclusively referring to the natural gas industry (excluding studies that also include the electricity industry); and the second step shows studies that give a competitive-managerial analysis perspective. 


\section{Main Research Conducted in the Economic Sphere}

Economic literature is basically founded on efficiency analysis, using a strictly econometric analysis approach on the basis of mainly parametric and non-parametric Data Envelopment Analysis (DEA) methods (Farsi, Filippini, \& Greene, 2006). Contributions recognize the presence both of economies of scale and economies of density although positions, in some cases, are divergent. For example, the optimal level for service management changes from research to research as well as the number of users necessary to define the most efficient dimensions for distributors, something that is decidedly variable (for a meta-analysis see Gullì, 2009).

Basically this great interest by economists for the efficiency dimension can be traced to the monopoly nature of the distribution companies and in particular to the fact that "prices of these companies are regulated according to their costs. As a result, these companies are tend to operate inefficiently” (Ertürk \& Türüt-Aşik, 2011, p. 1426). The most inefficient European nations include the Netherlands, the United Kingdom, and Norway (Plagnet, 2006).

Table 1 summarizes empirical studies analyzing the efficiency of regulated companies. More specifically it suggests a chronological review of main contributions on natural gas distribution. In almost all these studies (with the exception, for example, Carrington, Coelli, \& Groom, 2002) the panel is composed of integrated companies: working jointly in gas distribution and gas sale. The period under investigation was the 1890s and studies were conducted more with reference to the U.S. situation (Hollas \& Stansell, 1988; Granderson \& Linvill, 1999; Rossi, 2001; Carrington et al., 2002; Hollas, Macleod, \& Stansell, 2002; Goncharuk, 2008) than to the European (Farsi, Filippini, \& Kuenzle, 2007; Goncharuk, 2008) and Italian situations (Fraquelli \& Giandrone, 1997; Beccarello, 1998; Fabbri, Fraquelli, \& Giandrone, 2000; Fraquelli \& Erbetta, 2002; Erbetta \& Fraquelli, 2003; Erbetta \& Rappuoli, 2008).

Table 1

A Chronological Review of Main Contributions on Natural Gas Distribution in Economic Literature

\begin{tabular}{|c|c|c|c|c|}
\hline Author/s & $\begin{array}{l}\text { Panel/ } \\
\text { Cross-section }\end{array}$ & Time & Country & Main findings and conclusions \\
\hline $\begin{array}{l}\text { Hollas and Stansell } \\
(1988)\end{array}$ & 64 utilities & 1981 & US & $\begin{array}{l}\text { By a behavioral translog profit function that includes output and } \\
\text { price "shifters" for four types of companies, it is possible to } \\
\text { identify the relative efficiency of different types with respect to } \\
\text { each other, but it does not provide any firm-specific inefficiency } \\
\text { estimate. }\end{array}$ \\
\hline Kim and Lee (1996) & 7 companies & $1987-1992$ & Korea & $\begin{array}{l}\text { The output characteristics are important while estimating a } \\
\text { translog cost function for gas distributors. In addition to the labor } \\
\text { price and the unit price of pipeline, it is necessary to include the } \\
\text { customer density, the average "customer size" measured as } \\
\text { average consumption and the "supply rate" measured as the } \\
\text { number of total customers related to the number of total potential } \\
\text { customers. }\end{array}$ \\
\hline \begin{tabular}{|l|} 
Fraquelli and \\
Giandrone (1997) \\
\end{tabular} & 31 companies & 1992 & Italy & Absence of significant economies of scale. \\
\hline Beccarello (1998) & 114 companies & $1985-1993$ & Italy & $\begin{array}{l}\text { The presence of partial economies, referred to the labor factor, } \\
\text { indicates oversizing of personnel in small and medium size } \\
\text { companies. }\end{array}$ \\
\hline $\begin{array}{l}\text { Granderson and } \\
\text { Linvill (1999) }\end{array}$ & 20 companies & $1977-1987$ & US & $\begin{array}{l}\text { When using the non-parametric approach, the inefficiency } \\
\text { estimates are lower, the inefficiency ranking is more or less the } \\
\text { same. }\end{array}$ \\
\hline
\end{tabular}


(Table 1 continued)

\begin{tabular}{|c|c|c|c|c|}
\hline Author/s & \begin{tabular}{|l} 
Panel/ \\
Cross-section
\end{tabular} & Time & Country & Main findings and conclusions \\
\hline Fabbri et al. (2000) & 31 companies & $1991-1992$ & Italy & $\begin{array}{l}\text { The number of customers is more important than the amount of } \\
\text { gas supplied while explaining the variability of distribution costs. } \\
\text { Very low economies of scale, high economies of density, and the } \\
\text { significant role of the morphologic and demographic variables } \\
\text { characterize the nature of the technology. Better performance for } \\
\text { private operators indicates that the privatization process should go } \\
\text { on and the low degree of economies of scale confirms the benefits } \\
\text { of having many operators (yardstick competition). }\end{array}$ \\
\hline Rossi (2001) & 8 companies & $1993-1997$ & Argentine & $\begin{array}{l}\text { There is both a catching-up effect and a shift in the frontier, which } \\
\text { shows that the sector as a whole improved its efficiency in the } \\
\text { period under examination. }\end{array}$ \\
\hline $\begin{array}{l}\text { Carrington } \\
\text { et al. (2002) }\end{array}$ & 59 companies & $1997-1999$ & $\begin{array}{l}\text { Australia } \\
\text { and US }\end{array}$ & $\begin{array}{l}\text { Economies of scale are sources of efficiency for large-scale } \\
\text { distributors (more than } 400,000 \text { customers) and of inefficiency for } \\
\text { smaller ones (below 100,000 customers). }\end{array}$ \\
\hline $\begin{array}{l}\text { Fraquelli and } \\
\text { Erbetta (2002) }\end{array}$ & 33 companies & $1994-1999$ & Italy & The scale effect, in general, is hardly significant. \\
\hline Hollas et al. (2002) & 33 companies & $1975-1994$ & US & $\begin{array}{l}\text { There is little or no support for the assumption that enhanced } \\
\text { competition has altered economic efficiency of gas distributors. } \\
\text { The most significant effect of federal policy during the period } \\
\text { appears to be a general reduction in scale due to industry } \\
\text { restructuring and the promotion of competition. However, it does } \\
\text { not seem that the loss of scale adversely altered the overall } \\
\text { economic efficiency of gas distribution utilities. }\end{array}$ \\
\hline $\begin{array}{l}\text { Erbetta and } \\
\text { Fraquelli (2003) }\end{array}$ & 33 companies & $1994-1999$ & Italy & $\begin{array}{l}\text { The main results outline a marked profitability but a low growth } \\
\text { in the total factor of productivity. The reason is to be searched in } \\
\text { the price regulation system. More in detail, the public companies } \\
\text { and the ones specialized only in gas distribution show greater } \\
\text { performance than their counterparties. Quite ambiguous influence } \\
\text { is exerted by size variable. }\end{array}$ \\
\hline Farsi et al. (2007) & 26 companies & $1996-2000$ & Switzerland & $\begin{array}{l}\text { The customer density (number of customers per kilometer of } \\
\text { network) has a decreasing effect on costs, while the area size has a } \\
\text { positive effect. As for the economies of scale and density the } \\
\text { results are more or less consistent with the findings of studies } \\
\text { performed in other countries, as they provide evidence of } \\
\text { considerable economies of density but insignificant or weak } \\
\text { economies of scale. This implies that distributors could decrease } \\
\text { their average costs by increasing the output as long as they use the } \\
\text { same network but the extension of networks does not result in any } \\
\text { significant savings. }\end{array}$ \\
\hline $\begin{array}{l}\text { Erbetta and } \\
\text { Rappuoli (2008) }\end{array}$ & 46 companies & 1994-1999 & Italy & $\begin{array}{l}\text { Technology shows increasing returns only for the smallest units, } \\
\text { but such an effect has rapidly exhausted in favor of a regime of } \\
\text { constant returns to scale. An improvement of productivity may be } \\
\text { reached through an intensification of the merging process } \\
\text { involving local distributors operating at a small scale. Moreover, } \\
\text { the concentration process seems as an "attainable" objective since } \\
\text { the critical dimension, which permits the exploitation of positive } \\
\text { returns to scale, is quite small. }\end{array}$ \\
\hline Goncharuk (2008) & $\begin{array}{l}54 \text { and } 20 \\
\text { companies }\end{array}$ & 2005 & $\begin{array}{l}\text { Ukraine and } \\
\text { US }\end{array}$ & $\begin{array}{l}\text { The industry is unprofitable and its pure year-by-year losses } \\
\text { increase, that is related to negative influence of exogenous factors } \\
\text { that company management cannot control. The influence of the } \\
\text { factor of regional location on efficiency of the companies is weak. } \\
\text { It is established, that the scale factor plays an important role in } \\
\text { efficiency support: the optimal size of the gas distribution } \\
\text { company is the company with up to } 1.000 \text { persons. }\end{array}$ \\
\hline
\end{tabular}


Several of these studies examine the legislative and regulatory acts envisioned in the existing EU law. They refer, in particular, to directives 98/30/EC dated June 22nd, 1998 and 2003/55/EC dated June 26th, 2003.

Specifically, as far as the Italian situation is concerned, the various studies also refer to the regulation following start of the liberalization process in the natural gas industry. In particular they examine the following legislative acts: (1) the Letta decree that opens the gas market to competition, defining the institutional framework of the industry and assignment of the gas distribution service; and (2) decree No. 159 dated October 1st, 2007 with provisions regarding competition and the quality of essential services. They do not go into changes and developments within the legislative scope related to issue of the recent legislative and regulatory acts (Decree January 19th, 2011, Decree June 1st, 2011, and Decree October 18th, 2011), being considered in this paper.

\section{Timid Steps Towards a Perspective of Competitive Analysis}

Many managerial and competitive facets in the gas distribution industry are encompassed in studies conducted in the economic sphere and in the legislative and regulatory acts issued by the legislator.

These express, in particular, the management components of efficiency and cost, although considered from a general standpoint (contributions mentioned in Table 1), the structure of the market (AEEG, 2008), the organizational and structural configurations of the industry (decree No. 93 dated June 1st, 2011), regulation of distribution networks (Dorigoni, 2007; Beccarello \& Piron, 2008), the profitability and the financial structure of distribution companies (Erbetta \& Fraquelli, 2003; Giacomelli, 2008), as well as the usefulness of an effective regulation to preserve the benefits of vertical integration (Clò, 2006, 2008; Economides \& Glover, 2010), facilitating the dissemination of information and permitting creation of economies of scale and reductions in transaction costs.

Literature, however, is lacking a strictly competitive-managerial analysis approach that examines the intensity of competition of the Italian market following introduction of the Letta decree and in light of recent regulatory acts in 2011. Indeed some studies have recently been conducted with a qualitative analysis approach but none that aims at bridging this gap in research. In this regard, Dorigoni and Portatadino (2009) examine the Italian natural gas market structure and its legislation from a competitive standpoint but they focus on the impact of fees and on possible remedies and policy directions. The paper by Testa and Stagnaro (2011), which was not published in international journals, shows the main problems that have emerged in the years following the Letta decree, critically discussing them based above all on the new 2011 decrees and basically maintaining that the reduction of areas to 177 risks unintentionally having anti-competitive consequences if corrective actions are not taken. Stagnaro (2011), taking the same set-up, methodological approach, and analytical standpoint, deals with the theme of competition in the industry but only discusses assignment of the service by tender and the relevant problems between private and public companies: in particular he points out the unfavorable status of private parties following start of the tenders, their organization and the criteria that are taken (e.g., calculation of the concession fee).

\section{Methodology}

The methodological choices were constrained by the fact that the actual influences of the new regulation cannot be observed yet on the market (no tender according to new rules introduced in 2011 has taken place so far). Therefore the results could not be measured but only forecast. As a whole our study of the Italian natural gas industry can be interpreted as a single in-depth case study (Bonoma, 1985; Eisenhardt, 1989), a method that 
"focuses on understanding the dynamics present within single settings (Eisenhardt, 1989, p. 534) and suitable "when a fresh perspective is needed" (Eisenhardt, 1989, p. 549). The case study method is employed as an "illustration" (Siggelkow, 2007) to make a solid contribution, by focusing on dynamic processes.

In order to develop a sound reasoning and an "objective" assessment of the future scenario, we relied on a wide range of ancillary sources (Eisenhardt, 1989) for the purpose of answering the research question. In particular we reviewed academic studies on natural gas distribution, legislative acts, industry press, and reports from institutions and organizations (such as the Italian Regulatory Authority for Electricity and Gas and other research institutes) and we collected further material during conferences related to the issue under investigation. As regards academic studies, we also looked for analyses conducted both in Italy and in other countries, to strengthen the literature review and the critical assessment of the results.

The presentation of the evidences strongly depends on how data is collected to address the research objectives and on the researchers' choices (Golder, 2000). In particular, we decided to set up a $3 \times 3$ matrix in order to classify the collected data, considering respectively:

(1) The level of influences (industry; companies; users);

(2) The dimensions affected (structural dimension; economic dimension; service quality dimension).

The results are shown in a homogenous manner (Miles \& Huberman, 1994) in Table 2 and they are then illustrated separately for each of the three levels (industry, companies, users) so as to give a complete answer to the research questions. Thereafter the findings are discussed.

\section{Results}

The natural gas distribution industry, distribution companies and the users have undergone important changes following the legislative and regulatory acts issued as from 2000 in Italy. This section shows the results that were hoped for according to the rationale of the new regulation. In particular, it goes into the effects with regard to the three following dimensions:

(1) The structural dimension, relating to institutional composition and organizational, decision-making and financial framework;

(2) The economic dimension which basically regards the principles of management efficiency;

(3) The quality of service dimension, governed in Italy by law 481/1995. Choice of these dimensions resulted from analysis of the main areas of action that were intended to be directed by the various legislative acts under examination. Table 2 summarizes the results that were achieved.

\section{Expected Results on Natural Gas Distribution Industry as a Whole}

The natural gas distribution industry, following the start of liberalization in Italy in 2000, underwent substantial changes from the regulatory standpoint, changes which also affected its structural framework: as shown in Table 3 the number of businesses decreased, going from 480 in 2004 to 247 in 2010.

The pro-competitive choices characterizing enactment of the reform, along with greater financial discipline and implementation of the tariff system, have caused the natural gas distribution industry to concentrate, polarized between a few large companies (Table 4 shows the first 20 natural gas distribution groups in Italy in 2010 for volumes of gas and for market shares) and a multitude of municipality-owned and size companies (indicated by others in Table 4). Gas networks, in 2011 are managed by approximately 300 distributors (Stagnaro, 2011). The main market share, in particular, is held by the ENI group (totaling 22.9\% of all gas distributed in 2010). The second largest business, after purchasing, in 2002, great Italian and European 
businesses in the energy industry, is the Enel Rete Gas group, since 2009 subject to management and coordination of F2i Reti Italia. These industry leaders hold a one third market share.

Table 2

Expected Results at the Competitive Level Following the Start of the Reform in Natural Gas Distribution in Italy

\begin{tabular}{|c|c|c|c|}
\hline Expected results on... & Structural dimension & Economic dimension & Quality of service dimension \\
\hline \multirow[t]{2}{*}{$\begin{array}{l}\text {.. natural ga } \\
\text { distribution industry } \\
\text { as a whole }\end{array}$} & \multirow[t]{2}{*}{ Develop competition } & $\begin{array}{l}\text { Savings in technical working } \\
\text { costs for networks, central } \\
\text { functions and common } \\
\text { services }\end{array}$ & \multirow[t]{2}{*}{$\begin{array}{l}\text { Greater safety in product } \\
\text { supplies }\end{array}$} \\
\hline & & Greater savings & \\
\hline \multirow{3}{*}{$\begin{array}{lr}\ldots & \text { natural gas } \\
\text { distribution companies }\end{array}$} & $\begin{array}{l}\text { Independence from the organizational and } \\
\text { decision-making standpoints }\end{array}$ & \multirow{3}{*}{ Greater economies of scale } & \multirow{3}{*}{$\begin{array}{l}\text { Guaranteed information quality } \\
\text { and timeliness }\end{array}$} \\
\hline & Promote aggregation of distributors & & \\
\hline & $\begin{array}{l}\text { The need to raise financial and investment } \\
\text { capacities }\end{array}$ & & \\
\hline \multirow{4}{*}{... users } & \multirow{4}{*}{$\begin{array}{l}\text { Service universality: status of "eligible } \\
\text { customer" for all customers and freedom } \\
\text { of choice of the supplier }\end{array}$} & \multirow{4}{*}{ Reduction in rates } & $\begin{array}{l}\text { Safety in relationships with the } \\
\text { distributor }\end{array}$ \\
\hline & & & Continuity of service \\
\hline & & & Greater clarity and protection \\
\hline & & & Reduction of switching cost \\
\hline
\end{tabular}

Table 3

Changes in the Number of Distributors (Years 2004-2010)

\begin{tabular}{llllllll}
\hline 2004 & 2005 & 2006 & 2007 & 2008 & 2009 & 2010 \\
\hline 480 & 430 & 360 & 338 & 295 & 259 & 247 & \\
\hline
\end{tabular}

Note. Source: Compiled by the Authority of Electricity and Gas.

Table 4

Natural Gas Distribution Groups in Italy (Year 2010)

\begin{tabular}{lcc}
\hline Groups in the natural gas distribution industry & Volumes share \\
\hline Eni & $8,325.2$ & 22.9 \\
F2i Reti Italia & $3,665.0$ & 6.4 \\
Iren & $2,332.8$ & 6.4 \\
Hera & $2,330.1$ & 6.2 \\
A2A & $2,238.5$ & 4.0 \\
GDF SUEZ & $1,458.8$ & 3.2 \\
E.On & $1,164.0$ & 3.2 \\
Toscana Energia & $1,155.1$ & 2.3 \\
Asco Holding & 844.2 & 1.6 \\
Linea Group Holding & 580.4 & 1.5 \\
Estra & 558.4 & 1.4 \\
Acegas-Aps & 516.6 & 1.2 \\
AMGA-Azienda Multiservizi & 446.7 & 1.2 \\
Erogasmet & 418.3 & 1.0 \\
Gelsia & 371.4 & 1.0 \\
Energei & 360.4 & 0.9 \\
ACSM-AGAM & 329.2 & 0.9 \\
Gas Rimini & 326.3 & 0.9 \\
Gas Natural SDG & 321.3 & 0.9 \\
Agsm Verona & 317.9 & 22.7 \\
Others & $8,222.5$ & 100.0 \\
Total & $36,282.9$ & \\
\hline Note. Data are interim and refers to businesses which replied to the various editions of the annual survey. Source: Compiled by the \\
Authority of Electricity and Gas on the basis of declarations from businesses.
\end{tabular}


With the implementation of the "Third Energy Package” (decree No. 93 dated June 1st, 2011) assignment of the service is done by municipalities exclusively in an "associated" form per Minimum Territorial District (ATEM) and through a single tender (the previous rules shall apply for tenders that have already started) (Ref, 2011). The intention of the legislator, in doing this, is to further develop competition inside the industry, going beyond the pro-competition choices set in 2000. In the Letta decree, in fact, the roles, from the legislative standpoint, between local authorities and gas distribution service suppliers are clearly separated, to the extent that local authorities are only entitled to "steer, supervise, program, and control" distribution activities and for the most part they are not allowed to directly pursue this activity.

From the economic standpoint, on the basis of the productivity analyses provided by the Authority of Electricity and Gas (AEEG, 2008) according to which economies of scale in providing the service are significant for medium-small companies and weak for larger companies. The effect of economies of scale is significant at least up to a number of customers being served equal to approximately 300,000 whenever we consider both the technical working costs for networks and the costs for central functions and common services and up to 100,000 customers whenever, on the other hand, we only take the technical working costs for networks into account. In other words, exploitation of economies of scale in distribution, from the competitive standpoint, achieves savings in the technical working costs for networks (improved technical management), in central functions and in common services.

As to organization of tenders the industry tends towards economic efficiency: organizing tenders for a smaller number of Minimum Territorial Districts (ATEM) minimizes the administrative costs tied to carrying out the tenders and to control of the service provided by the concessionaires (Ref, 2011).

From the quality of service standpoint, given the importance of the inherent risks in fuel transportation and use, the Minister for Economic Development has given special attention to the safety of supplies. In this regard it has issued steering acts and taken measures to balance supply and demand on the Italian market. Moreover, it has governed the level of expected future demand, additional capacity now being programmed or under construction as well as quality and level of maintenance of networks and measures for coping with peaks in demand and shortage in supplies from one or more suppliers (decree dated June 1st, 2011).

\section{Expected Results on Natural Gas Distribution Companies}

The 247 gas distribution companies that do business in Italy are primarily local/regional in nature. They differ greatly in terms of form of ownership, legal status, geographic localization, and dissemination (the larger distributors are most present in the northern regions while local businesses prevail in the South), density of users, volumes of gas distributed, and concession relationships (Ref, 2011).

The natural gas distribution companies that belong to a vertically integrated company, according to the new legal acts, are independent from the organizational and decision-making standpoint from the other activities that are not related to distribution (art. 23 paragraph 1 of decree dated June 1st, 2011).

In addition several decrees push towards aggregation of distributors through a dual path, on the one hand: "local authorities are entitled to group together several bordering territorial districts to perform the tender with which to assign service of the related distribution facilities" (decree January 19th, 2011) and on the other hand the Authority for Electricity and Gas can take measures, including rate measures, that promote aggregation of natural gas distributors with fewer than 50,000 customers (art. 23 paragraph 4 of decree dated June 1st, 2011). The small- and medium-size companies, through this second decree, can overcome their size diseconomies by forms of aggregation (Ref, 2011). 
For the purpose of taking part in tenders the distribution companies underwent to verification of the existence of technical-managerial and economic-financial prerequisites. In particular they are forced to raise their own financial and investment capacities because the facilities development plan proposed in the tender is the criterion with the greatest weight for winning the tender (Ref, 2011).

Moreover, as requested by the authority, the regulation identifies the "optimum dimension" of the operator (Stagnaro, 2011) to be around 250,000 service points (AEEG, 2008): companies which are of this size would enjoy economies of scale and greater efficiency.

Distribution companies are forced to "make customer consumption data available to selling companies, while guaranteeing the quality and the timeliness of the information being provided" (art. 7 paragraph 4b of decree dated June 1st, 2011). This form of collaboration between parties to the supply chain would achieve mutual benefits from the standpoint of offering greater satisfaction to the end user: learning more about consumption clearly directs towards more efficient strategic decisions.

\section{Expected Results on Users}

At the structural level the market is very vast, including domestic customers (who purchase natural gas for their own use), users related to public services (including hospitals, nursing homes and rest homes, prisons, schools and other public and private facilities that carry out recognized assistance activities), civil customers (who purchase natural gas for their own domestic use), non-civil customers (who purchase natural gas that is not intended for their own domestic use) with consumption rates not in excess of 50,000 cubic meters per year. Table 5 breaks down customers by category of use. The data expresses the percentage shares of the customers of the distribution networks and their average consumption rates $\left(\mathrm{m}^{3}\right)$ as of December 31st for the period 2008-2010.

Table 5

Customer Breakdown by Category of Use (Years 2008-2010)

\begin{tabular}{|c|c|c|c|c|c|c|}
\hline \multirow[b]{2}{*}{ Category of use } & \multicolumn{2}{|l|}{2008} & \multicolumn{2}{|l|}{2009} & \multicolumn{2}{|l|}{2010} \\
\hline & $\begin{array}{l}\% \text { share } \\
\text { customers }\end{array}$ & $\begin{array}{l}\text { of Average } \\
\text { consumption } \\
\left(\mathrm{m}^{3}\right)\end{array}$ & $\begin{array}{l}\% \text { share of } \\
\text { customers }\end{array}$ & $\begin{array}{l}\text { Average } \\
\text { consumption } \\
\left(\mathrm{m}^{3}\right)\end{array}$ & $\begin{array}{l}\% \text { share of } \\
\text { customers }\end{array}$ & $\begin{array}{l}\text { Average } \\
\text { consumption } \\
\left(\mathrm{m}^{3}\right)\end{array}$ \\
\hline Cooking of foods & 10.9 & 203 & 10.7 & 203 & 10.6 & 203 \\
\hline Production of domestic hot water & 0.6 & 516 & 0.6 & 539 & 0.6 & 928 \\
\hline $\begin{array}{l}\text { Cooking of foods }+ \text { production of } \\
\text { domestic hot water }\end{array}$ & 10.9 & 318 & 10.7 & 319 & 10.1 & 313 \\
\hline Technological use & 1.1 & 21,610 & 1.0 & 20,659 & 1.0 & 23,227 \\
\hline Air-conditioning use & 0.1 & 1,973 & 0.1 & 2,110 & 0.1 & 2,635 \\
\hline Individual/centralized heating & 4.2 & 5,969 & 3.8 & 6,487 & 3.9 & 6,491 \\
\hline $\begin{array}{l}\text { Individual heating, cooking of foods, } \\
\text { production of domestic hot water }\end{array}$ & 62.0 & 1,052 & 63.3 & 1,074 & 64.2 & 1,098 \\
\hline Individual heating, cooking of foods & 6.9 & 1,038 & 6.5 & 997 & 6.3 & 1,085 \\
\hline $\begin{array}{l}\text { Individual heating, production of } \\
\text { domestic hot water }\end{array}$ & 1.5 & 3,587 & 1.5 & 3,675 & 1.6 & 3,783 \\
\hline $\begin{array}{l}\text { Centralized heating, cooking of foods, } \\
\text { production of domestic hot water }\end{array}$ & 0.4 & 5,082 & 0.3 & 5,414 & 0.3 & 6,402 \\
\hline $\begin{array}{l}\text { Centralized heating, production of } \\
\text { domestic hot water }\end{array}$ & 0.5 & 13,243 & 0.5 & 14,080 & 0.5 & 14,715 \\
\hline Technological use, heating & 0.9 & 18,032 & 0.9 & 16,739 & 0.9 & 17,647 \\
\hline Air-conditioning, heating use & 0.0 & 14,281 & 0.0 & 20,527 & 0.0 & 17,033 \\
\hline Total & 100.0 & 1,575 & 100.0 & 1,560 & 100.0 & 1,632 \\
\hline
\end{tabular}

Notes. Data for the year 2010, in addition to being interim, refers exclusively to businesses who replied to the various editions of the Annual Survey. Source: Compiled by the Authority for Electricity and Gas on the basis of declarations from businesses. 
Starting January 1st, 2003 every customer is held to be eligible for enjoying the natural gas distribution service and is free to choose his supplier. Eligibility, consequently, is no longer bound on gas consumption volumes. In other words, the natural gas distribution service is required to be universal.

From the economic standpoint, according to the authority, an increase in the size of the territorial districts in the natural gas distribution industry would entail benefits to consumers because of a significant reduction in distribution rates. However the distribution activity only affects to a limited extent (on the average little more than 10\%) the final price of the service of supply of gas for domestic use (Giacomelli, 2008).

The Authority, while regulating the quality of services, sets out minimum provisions levels for services with regard to end users, requires these to be periodically updated, sets automatic compensation in favor of users in case of failure to meet the preset requirements, prescribes service safety, and continuity by inspection of the distribution network and by measuring the degree of odorization of the gas as well as the maximum time periods for emergency response activities (resolution 236/2000 updated by resolution 168/2004). It also sets maximum time periods for carrying out the works for activating and deactivating the service (resolution 47/2000 updated by resolution 168/2004). In this regard, Table 6 shows a comparison of average actual and standard average times set out by the authority for all commercial services for customers with meters up to G6 in size, referring to the period 2003-2010 and concerning businesses with more than 5,000 end customers.

Table 6

Commercial Service Quality: Comparison of Actual and Standard Average Times as Set Out by the Authority (Years 2003-2010-Businesses With More Than 5,000 End Customers-Working Days)

\begin{tabular}{|c|c|c|c|c|c|c|c|c|c|}
\hline \multirow{2}{*}{ Provision of commercial services } & \multirow{2}{*}{$\begin{array}{l}\text { Authority } \\
\text { standard }\end{array}$} & \multicolumn{8}{|c|}{ Actual average time } \\
\hline & & 2003 & 2004 & 2005 & 2006 & 2007 & 2008 & 2009 & 2010 \\
\hline $\begin{array}{l}\text { Reactivation in case of shut-down due to } \\
\text { non-payment }\end{array}$ & 2.0 & 0.9 & 0.8 & 0.7 & 0.8 & 0.8 & 0.9 & 1.0 & 0.9 \\
\hline Deactivation of supply & 5.0 & 2.2 & 2.4 & 2.3 & 2.7 & 2.6 & 2.6 & 2.7 & 2.7 \\
\hline Activation of supply ${ }^{*}$ & 10.0 & 2.2 & 2.4 & 3.9 & 3.5 & 4.7 & 4.1 & 4.0 & 3.7 \\
\hline Execution of simple jobs & 15.0 & 6.6 & 6.7 & 7.4 & 5.7 & 7.3 & 6.2 & 5.7 & 6.5 \\
\hline Cost estimates for simple jobs & 15.0 & 5.4 & 5.6 & 6.2 & 5.7 & 5.4 & 5.4 & 5.5 & 5.6 \\
\hline Cost estimates for complex jobs ${ }^{* *}$ & 40.0 & & & & 12.8 & 12.9 & 13.0 & 10.7 & 11.0 \\
\hline $\begin{array}{l}\text { Reactivation of supply in case of interruption due } \\
\text { to potential hazard }\end{array}$ & 2.0 & & & & & & & & 0.6 \\
\hline Check of supply pressure & 10.0 & & & & & & & & 0.3 \\
\hline
\end{tabular}

Notes. $^{*}$ The standard was raised to 10 days starting January 1st, 2005 in accordance with resolution No. 40/04 (previously it was 5 days); ${ }^{* *}$ Specific standard envisaged starting in 2006. Source: Compiled by the Authority for Electricity and Gas on the basis of declarations from businesses.

The new acts aim at strengthening these services and, in particular, aim at ensuring greater clarity and protection for the user: they prohibit vertically integrated distribution systems from "creating confusion in their communication and brand policy regarding the distinct identity of the "supply" line of the vertically integrated company” (art. 23 decree dated June 1st, 2011); they set up one-stop desks where users can find all the information they require regarding their rights, existing legislation and procedures for settling disputes (art. 7, paragraph six of decree dated June 1st, 2011). Protection is also offered for users who find themselves in hardship by envisaging reduced rates.

One problem that is not yet efficiently governed regards change of supplier. Users, in particular, in addition to comparing the discount granted by the incumbent with that offered by the alternative supplier, are 
also forced to pay for the switching cost meaning the cost that every user, especially if he is small, must bear from the informative, administrative, and psychological (fear of receiving poorer quality services) standpoints when changing supplier.

\section{Discussion and Managerial Implication}

The results of the analysis provided an articulated overview of the new regulation current and expected influences on the three levels of the gas industry: the industry as a whole, the companies, and the users. Data about the trend of the scenario since 2000 (when the so-called Letta Decree was introduced) have shown a significant process of rationalization and aggregation among operators, whose number has decreased drastically. Nonetheless this process has not been straightforward and the level of competition still needs to be fostered. Similarly, significant improvements have been introduced into the service quality: the Italian Regulatory Authority for Electricity and Gas now defines the lowest acceptable levels of performance that distributors have to meet to avoid to be obliged to pay an automatic compensation fee to the user. The previous regime, based on the so-called "Service Charter", limited itself to setting out a few guidelines but left ample room to businesses to set out both minimum quality standards and the procedures and amounts of refunds to users. In short, the effects of the new regulation up to now on the three levels of analysis could be summarized as follows: (1) for the industry as a whole, there has been a certain increase in the level of competition; (2) as regards the companies, a quick process of aggregation has taken place; and (3) as to the users' level, there has been an enhancement of quality.

There is now a high level of expectations as regards the consequences of the regulation introduced in 2011 for the purpose of updating the industry's governance, increasing the level of competition. The rationale behind the new regulation seems internally consistent: by increasing the dimension of the tariff areas to be assigned through the concessions, economies of scale will emerge, creating more efficiency, and hence a positive impact on tariffs and transparency for the users. Additionally, the assignment of the concessions through tenders would create competition among the incumbents and the potential new entrants. Therefore, following the rationale of the new regulation, one may conclude that a win-win outcome should be achieved, with both an increase in competition and benefits for the natural gas users.

Nonetheless several aspects challenge this assumption and several observers have already expressed their skepticism about the potential beneficial effects of the reform at the level of competition. More precisely, Stagnaro (2011) and Testa and Stagnaro (2011) noted that the presence of economies of density may have been confused with the presence of economies of scale in the Italian gas distribution industry. The economies of scale for the gas distribution companies are mostly at an administrative level, including the purchase of sophisticated information systems or the bargaining power toward the suppliers (Mazzantini, 2006). Such economies of scale depend on the company size, but not on the geographic localization of the users. On the contrary, the economies of density are registered when users are concentrated in a small geographic area (Mazzantini, 2006).

The consequence of the misunderstanding between economies of scale and density led to the introduction of large tariff areas, each of which assigned to one distributor only. While there was no need for such users' geographic concentration to make the company's economies of scale work and while economies of scale required smaller geographic size to be present, the authors forecast that the final outcome will reduce the level of competition because incumbents will take benefits of such large tariffs areas. New entrants will have to face 
with high barriers, related to the sum of money that they would have to pay to the incumbent as compensation fee for the investments in the distribution equipment. The need of a high operator's investment capacity for the concession to be awarded will represent a further barrier.

It seems significant to compare these criticisms with the analysis conducted by Parker (1999) in the UK, which has been often considered as a model in this field, due to its long tradition of privatization of monopoly utilities. Since the 1980s, in UK the monopoly activities are policed by an industry regulator, to avoid exploitation of the consumer by the monopolist, meaning higher prices and poorer services. By observing the evolution of the liberalization process in the UK, Parker underlines the following points:

(1) "The extent of natural monopoly was often over-estimated [including] activities that were potentially competitive with the degree of competition masked by statutory monopoly given to the state-owned supplier" (Parker, 1999, p. 216). Hence several suggested "natural monopolies” were not justified in terms of economies of scale;

(2) The incentive to the companies to improve their efficiency is highly dependent on the type of regulation and it is fundamental to reduce discretion;

(3) Under privatization with regulation, economic benefits may be obtained by raising productivity and reducing prices for consumers, but regulation must have a leading role to achieve such objectives, for example by ensuring access charges for new companies at a level that does not represent a barrier to market entry.

Even if we take into account the institutional differences between Italy and the UK, it should be noted how the points raised by Parker (1999) for the UK are very close to those raised, for example, by Stagnaro (2011) and Testa and Stagnaro (2011) for the Italian context. The risk that the new regulation will involuntarily reduce instead of increasing the level of competition in the sector is then concrete. The potential solution described by Stagnaro (2011), consisting in giving the possibility of dividing each of the 177 areas into subareas managed by different operators, seems interesting. In this way, the companies will be free to find their optimum scale of operations, if need be through mergers and acquisitions.

\section{Conclusion, Limitation, and Further Research}

The analysis conducted in this paper highlighted, on the one hand, the rationale of the new regulation, which is intended to generate benefits in terms of an increased level of competition and of tariff reduction and quality enhancement for users. On the other hand, the study found and discussed several aspects and conceptual misunderstandings that will probably undermine the expected beneficial influences. Moreover the study suggests that only by considering the desired impacts at all three levels (industry as whole-companies-users) is it possible to have a clear picture both of the benefits and of the pitfalls of the new legislation.

Several limitations concern this paper. All the ideas are conceptually developed on the basis of ancillary source, above all of legal nature. The theme, subject matter of the analysis is subject to ongoing changes that make it difficult to achieve updated quantitative data.

The main limit of this study is tied to the fact that faced with a recently updated legislation, and it is not possible yet to record concrete results but only to envisage possible scenario development paths based on what has taken place from 2000 up to the present. Only when new tenders (or a part thereof) related to the 177 areas have been carried out will it be possible to check the effects in the field: this latter is a fruitful direction for future studies. It will also be helpful to examine developments in the wholesale market, not examined in this paper which only considered the retail market. 
In addition we are missing a theoretical reference model to use to examine, from a competitive-managerial standpoint, the impact of the measures implemented with the reform. This paper has chosen three dimensions (structural, economic, and quality of service) but, given the magnitude of the theme being examined, investigation areas could be enlarged to include, for example, the supply chain, risk management, service management, and marketing.

In this latter regard some studies have recently been carried out that refer to approaches to quality in the gas distribution service (Testa \& Vigolo, 2008; Vazio \& Repetto, 2011) but it would be even more significant to go into final market satisfaction facets, especially regarding domestic users. Here, regarding the dimensions of perceived and expected quality of the service, put forward in service management literature using the Gap Analysis Model (Parasuraman, Zeithaml, \& Berry, 1985; Zeithaml, Parasuraman, \& Berry, 1992; Baccarani, Ugolini, \& Bonfanti, 2010), it would be interesting to go deeper into the dimensions of technical and relational quality using first a qualitative and then quantitative analysis approach. The qualitative method would define the research items to use in a subsequent empirical investigation and to come to a measurement of the degree of satisfaction (or dissatisfaction) of the end user.

It could also be important, from the demand side, to study consumer perceptions regarding change of supplier, singling out the main critical events (Keaveney, 1995) and also to examine the critical elements inherent to this propensity (or lack of same) to switching. Research, in this regard, could investigate, in particular, which of the instruments available to users could hamper switching.

Given that the "optimum size" of natural gas distribution companies indicated by the public authority is not always the most effective size it could be interesting to examine this problem from a geomarketing perspective to provide an analysis of the reference market and the geographic reference area.

\section{References}

AEEG. (2000a). Delibera 47/2000 adjourned in the Delibera 168/2004. Retrieved from http://www.autorita.energia.it/it/docs/00/47-00.htm

AEEG. (2000b). Delibera 236/2000 adjourned in the Delibera 168/2004. Retrieved from http://www.autorita.energia.it/it/docs/00/236-00.htm

AEEG. (2008). Ipotesi per la formulazione di proposte in materia di individuazione di bacini ottimali di utenza. 3 giugno 2008. Retrieved from http://www.autorita.energia.it/allegati/docs/dc/08/015-08dco.pdf

AEEG. (2011). Annual report. Retrieved from http://www.autorita.energia.it/it/relaz_ann/11/11.htm

Antonioli, B. (2008). La distribuzione del gas in Italia: Riflessioni sulle proposte di riassetto. Management delle Utilities, 6(3), 90-92.

Baccarani, C., Ugolini, M., \& Bonfanti, A. (2010). A conceptual service quality map: The value of a wide opened perspective. Proceedings from 13th Toulon-Verona Conference "Organizational Excellence in Service”, Coimbra.

Beccarello, M. (1998). Price-cap e recupero di produttività: Suggerimenti dalla regolazione del settore gas. Economia pubblica, 28(4), 5-27.

Beccarello, M., \& Piron, F. (2008). La regolazione del mercato del gas naturale. Soveria Mannelli, Italy: Rubettino-Facco.

Bonoma, T. V. (1985). Case research in marketing: Opportunities, problems, and a process. Journal of Marketing Research, 22(2), 199-208.

Carrington, R., Coelli, T., \& Groom, E. (2002). International benchmarking for monopoly price regulation: The case of Australian gas distribution. Journal of Regulatory Economics, 21(2), 191-216.

Clò, A. (2006). Riflessioni a caldo sull'emergenza gas e dintorni. Energia, 1, 2-13.

Clò, A. (2008). Il futuro energetico italiano: Il tempo delle scelte. Energia, 3, 2-14.

Decree 159/2007. (2007). Retrieved October 1, 2007, from http://www.camera.it/parlam/leggi/decreti/07159d.htm 
Decree 164/2000. (2000). Letta Decree. Retrieved May 23, 2000, from http://www.parlamento.it/parlam/leggi/deleghe/00164dl.htm

Decree 18 October 2011. (2011). Determinazione dei Comuni appartenenti a ciascun ambito territoriale del settore della distribuzione del gas naturale. Retrieved from http://www.autorita.energia.it/it/docs/riferimenti/111028.htm

Decree 19 January 2011. (2011). Determinazione degli ambiti territoriali nel settore della distribuzione del gas naturale. Retrieved from http://www.sviluppoeconomico.gov.it/images/stories/normativa/DM-19-gennaio-2011completo.pdf

Decree 273/2005. (2005). Milleproroghe Decree. Retrieved December 30, 2005, from http://www.parlamento.it/parlam/leggi/decreti/05273d.htm

Decree 93/2011. (2011). $\quad$ Retrieved $\quad$ June $\quad 1, \quad$ from http://www.normattiva.it/uri-res/N2Ls?urn:nir:stato:decreto.legislativo:2011;093

Demsetz, H. (1959). The nature of equilibrium in monopolistic competition. The Journal of Political Economy, 67(1), 21-30.

Demsetz, H. (1964). The welfare and empirical implications of monopolistic competition. The Economic Journal, 74(295), 623-641.

Demsetz, H. (1968). Do competition and monopolistic competition differ? The Journal of Political Economy, 76(1), $146-148$.

Directive 03/55/CE. (2003). Retrieved June 26, from http://eur-lex.europa.eu/LexUriServ/LexUriServ.do?uri=OJ:L:2003:176:0057:0057:IT:PDF

Dorigoni, S. (2007). La riforma della distribuzione di gas in Italia. Milano, Italy: FrancoAngeli.

Dorigoni, S., \& Portatadino, S. (2009). Natural gas distribution in Italy: When competition does not help the market. Utilities Policy, 17(3-4), 245-257.

Economides, M. J., \& Glover, P. C. (2010). Energy and climate wars. London: Continuum Publishing.

Eisenhardt, K. M. (1989). Building theories from case study research. Academy of Management Review, 14(4), 532-550.

Erbetta, F., \& Fraquelli, G. (2003). Produttività e redditività nella distribuzione locale di gas naturale in Italia: Proprietà, diversificazione e scala operativa. HERMES Working Paper, No. 3, University of Eastern Piedmont. Retrieved from http://www.hermesricerche.unito.it/elements/wp03-3.pdf

Erbetta, F., \& Rappuoli, L. (2003). Estimating optimal scale and technical efficiency in the Italian gas distribution industry. HERMES Working Paper, No. 6, University of Eastern Piedmont. Retrieved from http://www.hermesricerche.unito.it/elements/wp03-6.pdf

Erbetta, F., \& Rappuoli, L. (2008). Optimal scale in the Italian gas distribution industry using data envelopment analysis. Omega, 36(2), 325-336.

Ertürk, M., \& Türüt-Aşik, S. (2011). Efficiency analysis of Turkish natural gas distribution companies by using data envelopment analysis method. Energy Policy, 39(3), 1426-1438.

Fabbri, P., Fraquelli, G., \& Giandrone, R. (2000). Costs, technology and ownership of gas distribution in Italy. Managerial and Decision Economics, 21(2), 71-81.

Farsi, M., Filippini, M., \& Greene, W. (2006). Application of panel data models in benchmarking analysis of the electricity distribution sector. Annals of Public and Cooperative Economics, 77(3), 271-290.

Farsi, M., Filippini, M., \& Kuenzle, M. (2007). Cost efficiency in the Swiss gas distribution sector. Energy Economics, 29(1), 64-78.

Fraquelli, G., \& Erbetta, F. (2002). Aspetti gestionali e analisi dell'efficienza nel settore della distribuzione del gas. CERIS-CNR, Working Paper, No. 3. Retrieved from http://www.ceris.cnr.it/ceris/workingpaper/2002/wp03_02_Fraquelli_Erbetta.pdf

Fraquelli, G., \& Giandrone, R. (1997). Performance delle imprese di distribuzione del gas in Italia. Energia, 18(4), 24-30.

Giacomelli, S. (2008). La distribuzione di gas naturale in Italia: l'attuazione della riforma e i suoi effetti. Questioni di Economia e Finanza. Occasional Papers, No. 21. Retrieved from http://www.bancaditalia.it/pubblicazioni/econo/quest_ecofin_2/qef_21

Golder, P. N. (2000). Historical method in marketing research with new evidence on long-term market share stability. Journal of Marketing Research, 37(2), 156-172.

Goncharuk, A. G. (2008). Performance benchmarking in gas distribution industry. Benchmarking: An International Journal, 15(5), 548-559.

Granderson, G., \& Linvill, C. (1999). Parametric and nonparametric approaches to benchmarking the regulated firm. Journal of Productivity Analysis, 12(3), 211-231.

Gullì, F. (2009). Economia di scala e dimensione ottimale nella distribuzione del gas: Una meta-analisi. Economia Delle Fonti Di Energia E Dell'ambiente, 52(3), 5-31. 
Hollas, D. R., \& Stansell, S. R. (1988). Regulation, interfirm rivalry and the economic efficiency of natural gas distribution facilities. Quarterly Review of Economics and Business, 28(4), 21-37.

Hollas, D. R., Macleod, K. R., \& Stansell, S. R. (2002). A data envelopment analysis of gas utilities' efficiency. Journal of Economics and Finance, 26(2), 123-137.

Keaveney, S. M. (1995). Customer switching behavior in service industries: An exploratory study. Journal of Marketing, 59(2), 71-82.

Kim, T. Y., \& Lee, J. D. (1996). Cost analysis of gas distribution industry with spatial variables. The Journal of Energy and Development, 20(2), 247-267.

Law 239/2004. (2004). Marzano law. Retrieved August 23, 2004, from http://www.camera.it/parlam/leggi/04239l.htm

Law 481/1995. (1995). Retrieved November 14, 1995, from http://www2.agcom.it/l_naz/l_481_141195.htm

MacAvoy, P. W. (2000). The natural gas market: Sixty years of regulation and deregulation. New Haven, Conn.: Yale University Press.

Mazzantini, G. (2006). La distribuzione e la vendita del gas fra economie di scala e di densità. Management delle Utilities, 2, 44-56.

Miles, M. B., \& Huberman, A. (1994). Qualitative data analysis: An expanded sourcebook (2nd ed.). Thousand Oaks: Sage Publications.

Parasuraman, A., Zeithaml, V. A., \& Berry, L. L. (1985). A conceptual model of service quality and its implications for future research. Journal of Marketing, 49(4), 41-50.

Parker, D. (1999). Regulation of privatised public utilities in the UK: Performance and governance. International Journal of Public Sector Management, 12(3), 213-235.

Plagnet, M. A. (2006). Use of benchmarking methods in Europe in the electricity distribution sector. Proceedings from 5th Conference on Applied Infrastructure Research (INFRADAY), Berlin.

Ref. (2011). Pronte le norme per le gare nella distribuzione: E le imprese? Newsletter Osservatorio Energia, 13(149-150), 9-16.

Rossi, M. A. (2001). Technical change and efficiency measures: The post-privatization in the gas distribution sector in Argentina. Energy Economics, 23(3), 295-304.

Siggelkow, K. (2007). Persuasion with case studies. Academy of Management Journal, 50(1), 20-24.

Stagnaro, C. (2011). La razionalizzazione anticompetitiva: Il caso della distribuzione locale del gas. Ibl Briefing Paper No. 105. Retrieved from http://brunoleonimedia.servingfreedom.net/BP/IBL_BP_105_Distribuzione_Gas.pdf

Stagnaro, C., \& Testa, F. (2009). Nell'ambito grosso sta l'azienda buona? Alcune riflessioni sul caso della distribuzione locale del gas. Management delle Utilities, 7(1), 20-25.

Testa, F. (2007). Questioni calde nella distribuzione del gas: Il tema delle gare. Management delle Utilities, 5(4), 71-73.

Testa, F., \& Stagnaro, C. (2011). Ambiti di distribuzione del gas e costruzione di un mercato concorrenziale: Alcune riflessioni critiche. Management delle Utilities, 9(4), 30-35.

Testa, F., \& Vigolo, V. (2008). Corporate dimension and quality performance: An empirical analysis from the gas distribution sector in Italy. Proceedings from 11th Toulon-Verona Conference on Quality in Services, Florence.

Vazio, D., \& Repetto, G. P. (2011). $4^{\mathrm{a}}$ Indagine: Il mercato domestico. Osservatorio sul comportamento dei consumatori tutelati nel settore elettrico e del gas. Relazione presentata al Convegno di “Acquirente Unico" su liberalizzazione mercato energetico e del gas in Italia, Roma, 24 giugno. Retrieved from http://www.au-energia.it/docs/7188_Presentazione\%20_carpette_RIE-IV\%20indagine24062011.pdf

Zeithaml, V. A., Parasuraman, A., \& Berry, L. L. (1992). Strategic positioning on the dimensions of service quality. In T. A. Swartz, D. E. Bowen, \& S. W. Brown (Eds.), Advances in services marketing and management (Vol. 2). Greenwich, Conn.: JAI Press. 